\title{
Wind-related Disasters in Bangladesh and Changes in Regulations and Practice
}

\author{
Taiichi HAYASHI *
}

\section{INTRODUCTION}

Bangladesh has been frequently damaged by tropical cyclones and severe local storms including tornadoes. Cyclones in the Bay of Bengal occur in March, April and May of the pre-monsoon season and in October and November of the post-monsoon season. Tornadoes relating to severe local storms also mainly occur in the pre-monsoon season.

The damages by high winds of cyclones and tornadoes were very serious to the human life of Bangladesh because the infra-structure were very fragile. The number of death in cyclone in November 1970 was reported as three hundred thousand or five hundred thousand, which is one of the worst disasters in the world in the past. This cyclone is recognized as one of the triggers of the independence of Bangladesh in1971. The number of death during the cyclone of April 1991was around one hundred forty thousand ${ }^{1), 2)}$.

In this report, the general view of tropical cyclones and severe local storms are described with estimated wind speeds estimated by the meteorological data and relating damages. The Cyclone "Sidr" in 2007 and Tornado in 1996 in Tangail in the middle of Bangladesh are typical case studies of cyclone in the Bay of Bengal and severe local storm on this report.

\section{CYCLONE "Sidr"}

This Cyclone "Sidr" in the middle of November, 2007, was one of the severest cyclones before in the last three decades years. The Cyclone “Sidr” occurred at 21BST (Bangladesh Standard

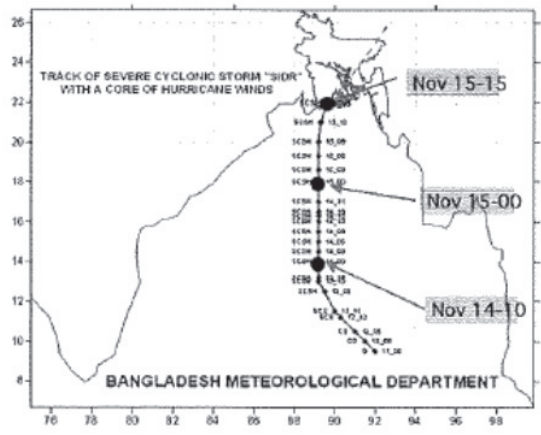

Fig.1 Path of Cyclone “Sidr” reported by Bangladesh Meteorological Department. Indicated times are in UTC.

Time) or 15UTC on 11th November, 2007 in the southern area of the Bay of Bengal and landed at the southern coast of the Bay of Bengal in Bangladesh at 21BST on 15th November, as shown in the path of the cyclone "Sidr of Fig.1.

Fig.2 shows the satellite image of the Cyclone "Sidr" at 0530UTC of November 15th, 2007, as the mature stage of this cycone by the meteorological Satellite "Kalpana” of India Meteorological Department (IMD). The diameter of the cyclone is around $400 \mathrm{~km}$ and the clear eye exixted in the center of the cyclone. Bangladesh Meteorological Department (BMD) reported that the minimum pressure of $944 \mathrm{hPa}$ and the peak gust of $69 \mathrm{~ms}^{-1}$ were observed at the time of landing on the coast of Bangladesh.

* Professor, Center for South East Asian Studies, Kyoto University 


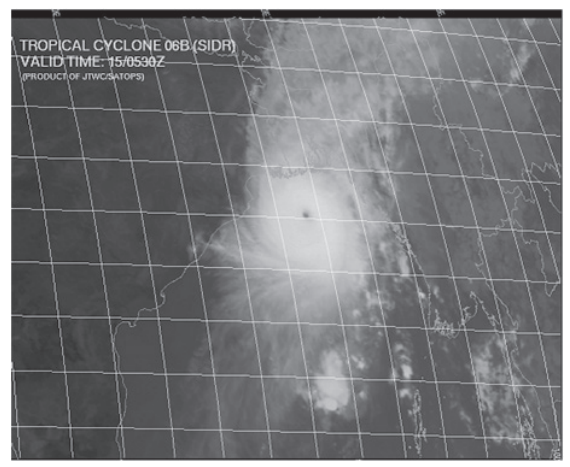

Fig.2 Satellite image of the Cyclone "Sidr" by "Kalpana of IMD.

The distribution of affected area is shown in Fig.3 and the main damaged area concentrated at the coastal part of the southwestern region of Bangladesh. The total number of death was 3,363 and that of missing persons 871. The affected persons were around eight million and ninety thousand and damaged houses were one million and fifty two thousand.

The typical damaged house by the high wind is shown in Fig.4, which was located at Sharankhola village of Barguna, Kulna.

BMD issued the early warning of evacuation to the area at the

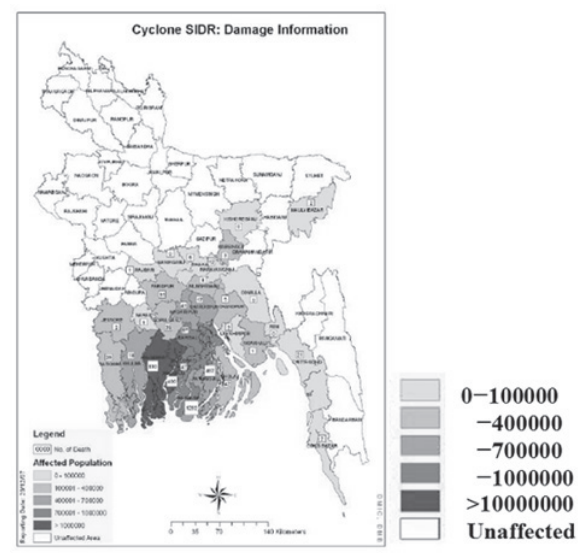

Fig.3 Distribution of Affected area reported by the

Disaster Management Bureau²).

coastal area of the Bay of Bengal, where the landing of the cyclone would be expected using the analytical results of weather charts, aerological data, satellite data, radar data etc. Two Doppler radars were installed at Khepupara and Cox's bazar for monitoring the approach of cyclones at the coast of the Bay of Bengal and are utilized for the exact prediction of the

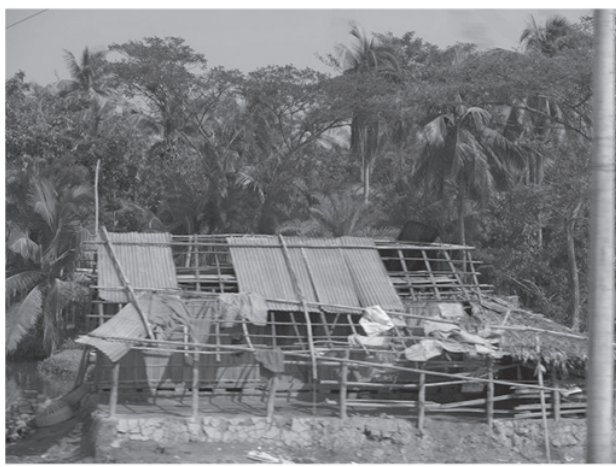

Fig.4 Damaged house in Sharankhola.

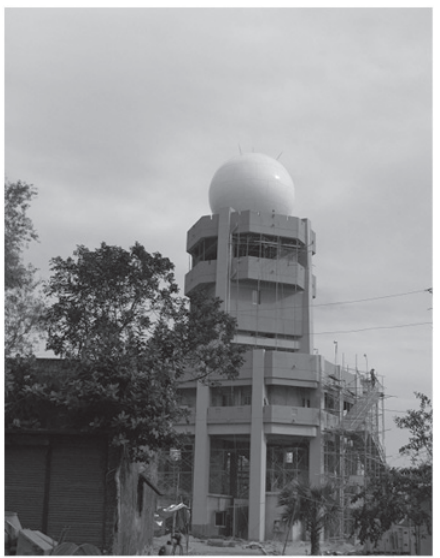

Fig.5 Doppler Radar at Khepupara

path of cyclones and the appropriate warning (Fig.5). People in the dangerous area evacuate in cyclone shelters. After the cyclone in 1991, the cyclone shelters prevailed as the most powerful and fundamental counter measure to save the human

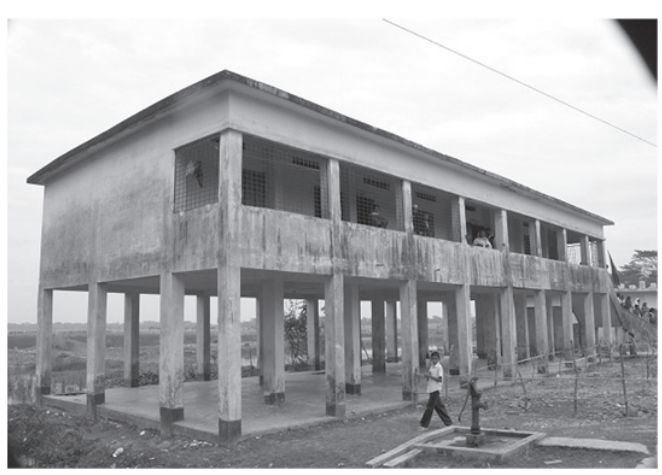

Fig.6 Cyclone Shelter 
life in Bangladesh. These cyclone shelters have high story floor and RC structures.

More than 2,000 cyclone shelters were constructed already by Bangladesh government as well as the financial support of many other countries in the world.

\section{TORNADO in TANGAIL on 13th MAY, 1996}

Typical twenty five tornadoes between 1961 and 2013 are listed in Table 1 together with main damages. The number of death is more than one hundred at one tornado in thirty three tornadoes. One thousand and three hundred persons died at Manikganj in 19894) $\quad$ Fig.7 shows the monthly occurrence of

Table1 Typical Tornado Events in Bangladesh between1961 and $2013^{4)}$.

\begin{tabular}{l|l|l|l|l|l|r|r|}
\hline Year & Month & Day & $\begin{array}{l}\text { Time(UTC) } \\
\text { HHMM }\end{array}$ & Location & Region & Death & Injured \\
\hline 1961 & 3 & 19 & $10: 00$ & Faridpur & C & 210 & \\
\hline 1963 & 4 & 19 & $10.50-12.30$ & North BD & NC, NW & 300 & \\
\hline 1964 & 4 & 11 & $10: 30$ & $\begin{array}{l}\text { Magura, } \\
\text { Narail }\end{array}$ & WC & $500+$ & \\
\hline 1969 & 4 & 14 & $10: 45-11: 15$ & Demra & C & 922 & 16,511 \\
\hline 1972 & 4 & 1 & $12: 30$ & Mymensingh & NC & $200+$ & \\
\hline 1973 & 4 & 17 & $08: 45$ & Manikganj & C & 681 & 1,000 \\
\hline 1974 & 4 & 11 & Local afternoon & Bogra & NW & 100 & 75 \\
\hline 1976 & 5 & 9 & Local evening & Narayanganj & C & 1 & 42 \\
\hline 1977 & 4 & 1 & $10: 00$ & Faridpur & C & 500 & 6,000 \\
\hline 1986 & 4 & 14 & $12: 00$ & Copalgonj & C & 120 & \\
\hline 1989 & 4 & 26 & $12: 30$ & Manikganj & C & 1,300 & Innumerablele \\
\hline 1990 & 4 & 20 & Local afternoon & Siraiganj & NW & 76 & 2,000 \\
\hline 1991 & 5 & 7 & Local afternoon & Gazipur & C & 46 & 400 \\
\hline 1995 & 4 & 8 & $11: 00$ & Munshiganj & C & $40+$ & Sevral hundreds \\
\hline 1996 & 5 & 13 & $10: 30-12: 00$ & $\begin{array}{l}\text { Tangail, } \\
\text { Jamalpur }\end{array}$ & C, NC & $700+$ & 30,000 \\
\hline 1998 & 4 & 8 & 05.10 & Nilphamari & NW, C & 21 & \\
\hline 1999 & 3 & 26 & $12: 00$ & Dhaka & C & 2 & 60 \\
\hline 2002 & 4 & 26 & $12: 20-15: 11$ & $\begin{array}{l}\text { Bogra, } \\
\text { Dhaka }\end{array}$ & NW, C & 25 & \\
\hline 2003 & 5 & 4 & $14: 00$ & Bbaria & EC & 22 & \\
\hline 2004 & 4 & 14 & $13: 40$ & Mymensingh & NC & 111 & 1,700 \\
\hline 2005 & 3 & 20 & $12: 45$ & Gaibandha & NW & 66 & 4,680 \\
\hline 2010 & 4 & 13 & $17: 30-19: 30$ & $\begin{array}{l}\text { North } \\
\text { Districts }\end{array}$ & NW, NC & 139 in India & \\
\hline 2011 & 4 & 4 & $13: 00$ & $\begin{array}{l}\text { Dhaka, } \\
\text { Mymensingh }\end{array}$ & C, NC & 12 & \\
\hline 2012 & 4 & 28 & $16: 00$ & Dhaka & C & 7 & \\
\hline 2013 & 3 & 22 & $11: 00$ & Bbaria & EC & 36 & 500 \\
\hline
\end{tabular}

severe local convective storms (SLCS) in Bangladesh between 1990 and 2005. The SLCS occurrences concentrates in the pre-monsoon season of March, April and May),6).

The spatial distribution of SLCS is shown in Fig.8. Dots indicates the location of the headquarters of districts and the shade and the size of a dot indicate the magnitude of occurrence of SLCS for each district. Main occurrence districts are Dhaka district (indicated as “D” in Fig.8), with one hundred and eleven events, "N" is Netrakona with one hundred and nine events, "T" is Tangail with ninety events, "S" and "C" are Sirajganj and Comilla with eighty three events. The main occurrence area of SCLS is the middle part of Bangladesh.

One of the typical tornado occurred in Tangail district at 1830BST or 12UTC on 13th May, 1996. The tornado path

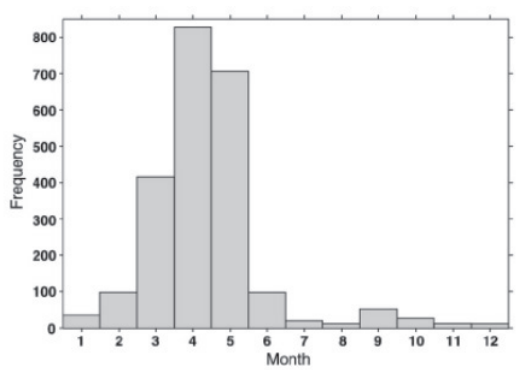

Fig.7 Monthly occurrence of severe local convective storms between 1990and 2005).

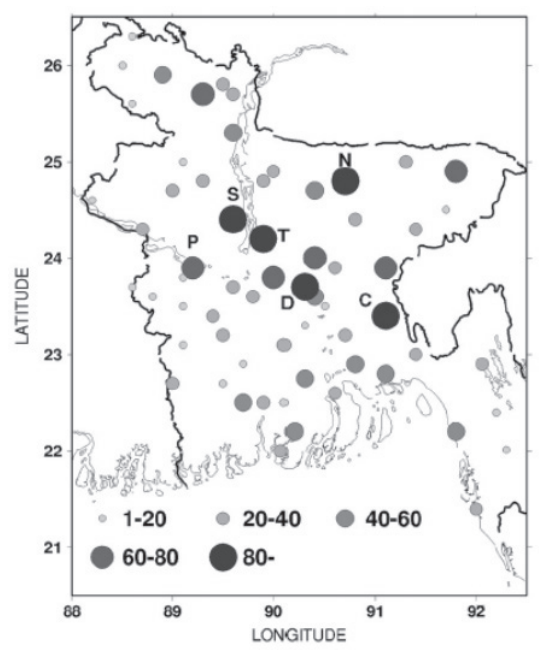

Fig.8 Spatial distribution of severe local convective storms in Bangladesh between 1990 and 20055).

and the area of damaged area are shown in Fig.9. The Fujita scale of this tornado was F3.5 and the length was $80 \mathrm{~km}$ and the width $3 \mathrm{~km}$ in maximum ${ }^{7}$.

The statistics of damages are shown in Table 2, and the death were 525, the injured 32,601, the affected 84,100 and the destroyed houses 35,691. The most damaged area were Goalpur, Kalihatti and Bashail tanas in Tangail district, $120 \mathrm{~km}$ north of Dhaka. The damaged area is traced southward running through Tangail district and the direction changed to southwest at the southern end of this district in Fig.9. The wind speed was estimated by this damage as F3.5. The damaged school building is shown in fig.10, of which structure was RC. The first trial of tornado shelter is conducted in the rural village in Tangal to evacuate under the ground by the support of Japan program. 
Table 2 Main damages in Tangail tornado, 1996.

\begin{tabular}{|c|c|c|c|}
\hline \multirow{3}{*}{$\begin{array}{l}\text { Personal } \\
\text { Damages }\end{array}$} & \multicolumn{2}{|c|}{ The Dead } & 525 \\
\hline & \multicolumn{2}{|c|}{ The Injured } & 32,601 \\
\hline & \multicolumn{2}{|c|}{ The affected } & 84,100 \\
\hline \multirow{3}{*}{$\begin{array}{l}\text { Damaged } \\
\text { Structures }\end{array}$} & \multicolumn{2}{|c|}{\begin{tabular}{|r|} 
Houses \\
\end{tabular}} & 35,691 \\
\hline & \multirow{2}{*}{ School } & Completely damaged & 16 \\
\hline & & Partially damaged & 34 \\
\hline \multirow{2}{*}{$\begin{array}{l}\text { Damafged } \\
\text { Water } \\
\end{array}$} & \multicolumn{2}{|c|}{ Public well } & 500 \\
\hline & \multicolumn{2}{|c|}{ Proivate well } & 1,000 \\
\hline Damaged Food & \multicolumn{3}{|c|}{$15 \%$ of whole crops } \\
\hline \multirow{3}{*}{$\begin{array}{l}\text { Damaged } \\
\text { Cattle }\end{array}$} & \multicolumn{2}{|l|}{ Cow } & 2,800 \\
\hline & \multicolumn{2}{|c|}{ Sheep } & 1,410 \\
\hline & \multicolumn{2}{|c|}{ Hen \& Cock } & 404,000 \\
\hline
\end{tabular}

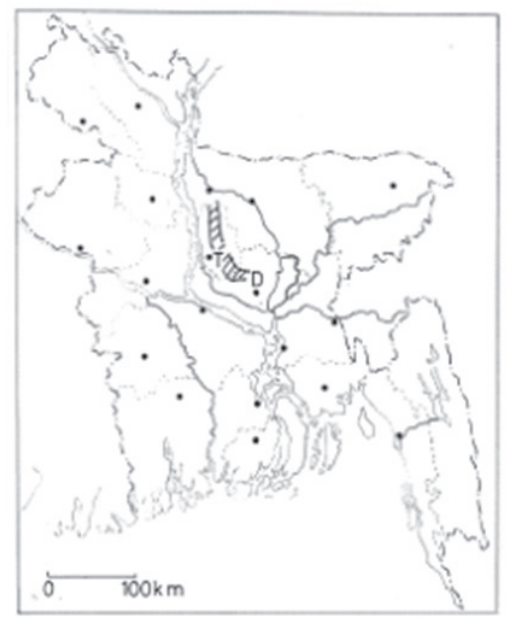

Fig.9 Path and damaged area of tornado in Tangail on May 13th, 1996. "D” and “T” indicate Dhaka and Tangail Shade is damaged area.

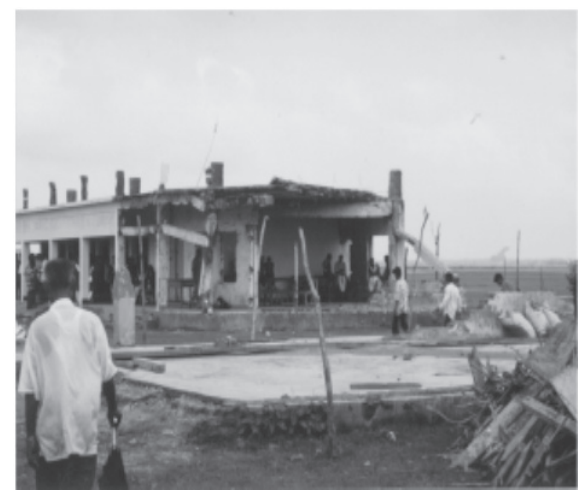

Fig.10 Damage of school building at Bashail.

\section{REFERENCES}

1) Hadar, R. 'Cyclone' 91 An wnvironmental and perceptional study”, Bangladesh center for adcvanced studies, 60pp., (1991)

2) Hayashi, T, "Meteorological characteristics of 1991 cyclone", Research report on natural disasters, "Storm surge and severe wind disasters casued by the 1991cyclone in Bngladesh”, ed. Katsura, J., 101pp., (1992)

3) Disaster Management Bureau, "Situation report, Summary of Cyclone Sidr response”, 9pp., (2007)

4) Akter, F. "Environmental conditions and dryline influence on severe local convective storm occurrence in the pre-monsoon season of Bangladesh”, $\mathrm{PhD}$ thesis of Kyoto University, pp.91, (2014)

5) Yamane, Y., Hayashi, T., Dewan A. M. and Akter, F., "Severelocal convective storms in Bangladesh: Pat 1. Climatology”, Atmospheric Resarch, 95, pp. 400-406., (2010)

6) Yamane, Y., Hayashi, T., Dewan A. M. and Akter, F., "Severelocal convective storms in Bangladesh: Pat 1. Environmental conditions”, Atmospheric Resarch, 95, pp. 407-418., (2010)

7) SMRC Newletter, “Tornadoof 13 May, 1996 over Tangail of Bangladesh”, Vol. 1, No. 2, 4pp.

8) Hayashi, T., "The tornado in the Tangail district of Bangladesh, on May 13 of 1996”, Report of Disaster Decade, pp. 25-33, (1997) 